\title{
SUSCEPTIBILITY OF WISEANA SPECIES TO DIFLUBENZURON AND IMPLICATIONS FOR FIELD APPLICATIONS
}

\author{
C.M. FERGUSON
}

\author{
AgResearch, Invermay Agricultural Centre, Private Bag 50034, Mosgiel
}

\begin{abstract}
Porina control using diflubenzuron is popular due to its low cost and benign environmental effects. The level of control in Otago and Southland, however, can be variable and may be associated with species diversity in the region. In this investigation, larvae of Wiseana cervinata, W. copularis, W. jocosa and W. mimica, were exposed to diflubenzuron in two laboratory bioassays. All species were killed, with small larvae killed more quickly than large. There were only minor differences in susceptibility between species. Adult flights at three sites showed variation in the main flight period suggesting that larvae in pasture in autumn would cover a wide size range. This was confirmed by field sampling. The timing and frequency of diflubenzuron applications should be considered in conjunction with the phenology of adult flight and subsequent larval development, and climatic conditions affecting larval survival.
\end{abstract}

\section{INTRODUCTION}

Porina, the common name for Wiseana (Lepidoptera: Hepialidae), consists of a complex of species that rank as major pasture pests in many areas of New Zealand. The family has recently been revised (Dugdale 1994) and seven species described, but Brown et al. (1999) using DNA technology has suggested that further divisions may be warranted. The adults can, with reasonable reliability, be identified using morphological techniques (Dugdale 1994) and this has enabled increased understanding of adult flight patterns (Ferguson et al. 1999). Larval identification using morphological characters is not reliable but is possible using allozyme electrophoresis (Herbert 1994) and may be possible with DNA technologies. To date, practical large-scale identification methodologies have not been developed and the significance of each species as an agricultural pest has not been determined. Herbert (1994) showed that mixed populations occur within pastures but many studies in the past have not attempted to identify species of porina and have generally regarded them as a single complex. This means that research findings must be viewed with caution when biological or behavioural aspects of porina are being considered. Similarly the results of research based on adult taxonomy, which has subsequently been updated, may be unreliable.

Porina is a very significant pest in the southern South Island where species diversity is the greatest (Barratt et al. 1990; Dugdale 1994). Historically in this region, porina control has been attempted by the use of broad-spectrum organophosphate insecticides applied after pasture damage has appeared. Differences between porina species are unlikely to affect this type of control. More recently there has been a move away from these insecticides towards moulting hormone application and pasture and stock management techniques. The level of control achieved with these is variable (Ferguson et al.1989; Ferguson et al.1996; Stewart and Ferguson 1989; Stewart and Ferguson 1992). These methods may be more affected by differences between species and a greater understanding of porina biology and behaviour may be required to maximise their effectiveness.

This investigation aimed to evaluate the effect of the moulting hormone diflubenzuron on different species and sizes of porina in laboratory bioassays and 
interpret the results with respect to observed adult flight patterns and larval growth in the field.

\section{Laboratory bioassays}

\section{METHODS}

Adult Wiseana females were collected at night from the Taieri Plain and Alexandra (Otago), Lumsden (Southland) and Makuri (Waiarapa) between October 1999 and January 2000. These moths were held individually in plastic vials until they laid eggs. The moths were identified to species by examining the bursa copulatrix (Dugdale 1994). Further divisions were made for two species based on the time of year they were collected (Table 1). The eggs were surfaced sterilised using 1 ppm copper-oxychloride solution and held on moist filter paper until they hatched when the larvae were transferred to petri dishes $(100 \times 100 \times 18 \mathrm{~mm})$ filled to $10 \mathrm{~mm}$ with fine pine bark which had passed through a $2 \mathrm{~mm}$ mesh. An artificial diet based on white clover and carrot ((Dodgshun 1970) modified by A. Popay (pers. comm.)) was supplied to the larvae as required. When $10 \mathrm{~mm}$ long, the larvae were placed in individual $60 \mathrm{ml}$ specimen containers and reared at $20^{\circ} \mathrm{C}$ except for a 3 week period in mid-summer when larvae collected in October and intended for use in bioassay 2 were held at $5^{\circ} \mathrm{C}$ to delay development.

Bioassay 1 in December 1999 used 10-19 mm long larvae of $W$. cervinata (early), $W$. copularis (early), W. jocosa and W. mimica, all reared from eggs laid by moths flying from early to mid-October. Bioassay 2 in April 2000 used larvae from the same groups when they measured between 25 and $34 \mathrm{~mm}$ but also included $W$. cervinata (late) larvae from moths collected in mid December (16-24 mm) and W. copularis (late) from moths flying in late January $(9-11 \mathrm{~mm})$. Head capsule widths were measured at bioassay commencement and when the larvae died.

In bioassay 1, 13 larvae of each species were given diet containing a 'field' rate (see below) of diflubenzuron and a further 13 were provided with untreated diet (control). In bioassay 2, 15 larvae (except $W$. copularis (early) $n=10$ ) of each group were given either diet with the 'field' or a low (one tenth 'field') rate of diflubenzuron and a further 15 (W. copularis (early) $n=3$ ) untreated diet. In all cases the diets were supplied as required for 4 weeks after which all larvae were given fresh untreated diet. The amount of diet provided was weighed prior to presentation and when not completely consumed, the proportion left was visually estimated. Survival of the larvae was assessed every 3-4 days and the data were analysed using a generalised linear model with a binomial distribution and a canonical link.

The amount of diflubenzuron in the 'field' diet was determined by estimating pasture production $(3000 \mathrm{~kg} \mathrm{DM} / \mathrm{ha})$ over the expected time necessary to kill porina in the field (4-8 weeks) using diflubenzuron at the recommended rate (50 g/ha Dimilin $25 \mathrm{~W})$. Dimilin was then incorporated into the artificial diet at the equivalent ratio of product to diet dry weight $\left(0.017 \times 10^{-3} \mathrm{~g}\right.$ Dimilin $25 \mathrm{~W} / \mathrm{g}$ diet $)$.

\section{Field}

Porina flights were measured, by light trapping moths one night per week, at three sites, Owaka (South Otago), Mahinerangi (East Otago Plateau) and Lumsden between late September 1999 and late February 2000. In late March/early April 2000 larvae were collected by digging 40-80 spade spits ( $150 \times 150 \times 200 \mathrm{~mm}$ deep) from two pastures close to each site. Larvae were extracted from the top $50 \mathrm{~mm}$ of each sample in Berlese funnels. Soil below $50 \mathrm{~mm}$ was sorted by hand in the field. The lengths and head capsule widths of all larvae collected were measured

\section{Laboratory bioassays}

\section{RESULTS}

The mean head capsule widths of larvae at the beginning of bioassay 1 were $W$. cervinata (early) 1.3 (range 1.0-1.7, SEM=0.07), W. copularis (early) $1.3 \mathrm{~mm}$ (range 1.0-1.7, SEM=0.08), $W$. jocosa $1.3 \mathrm{~mm}$ (range 1.2-1.6, $\mathrm{SEM}=0.06)$ and $W$. mimica 1.8 $\mathrm{mm}$ (range 1.6-2.0, SEM=0.04). In this bioassay $98 \%$ of the larvae provided with diet incorporating diflubenzuron died within 14 days with no differences between species. 
Conversely $98 \%$ of the larvae given untreated diet were alive after 14 days. Only three larvae, all $W$. jocosa, were observed to have successfully completed a moult while feeding on the diflubenzuron-treated diet. The single $W$. jocos $a$ that survived treatment continued to develop normally.

Head capsule widths at the beginning of bioassay 2 were: $W$. copularis (late) 1.2 $\mathrm{mm}$ (range 0.89-1.44, SEM=0.49), W. copularis (early) $2.9 \mathrm{~mm}$ (range 2.40-3.20, $\mathrm{SEM}=0.04), W$. cervinata (late) $2.24 \mathrm{~mm}$ (range 1.80-2.80, SEM=0.50), W. cervinata (early) $3.0 \mathrm{~mm}$ (range 2.40-3.20, SEM=0.04), W. jocosa $3.0 \mathrm{~mm}$ (range 2.80-3.40, SEM=0.03) and $W$. mimica $3.07 \mathrm{~mm}$ (range 2.68-3.07, SEM=0.03).

In bioassay 2 survival of $W$. copularis (late) and $W$. cervinata (late) larvae in both diflubenzuron diet treatments was significantly lower $(\mathrm{P}<0.01)$ than other larvae after 14 days and almost all larvae were dead by day 28 (Table 1 ). There were no differences between the other species groups at day 14 in either diflubenzuron treatment, or between any group within the 'field' rate treatment by day 28 . In the low rate treatment $W$. mimica survival was higher $(\mathrm{P}<0.05)$ than all other species except $W$. copularis (early) after 28 days (Table 1 ). By day 49 only one larva (W. mimica) remained alive in the 'field' rate treatment and six (four W. mimica, one W. cervinata (early) and one $W$. copularis (early)) remained in the low rate treatment. Subsequent development of these larvae appeared normal. Survival of the control larvae remained unchanged. The amount of diet consumed in the diflubenzuron treatments varied considerably within and between size classes. Generally larger larvae $(25-34 \mathrm{~mm})$ consumed more $(1.14$ $-2.44 \mathrm{~g}$ diet $)$ than smaller larvae $(9-19 \mathrm{~mm})(0.20-0.50 \mathrm{~g})$ with all larvae appearing to feed until 3-4 days prior to death. The presence, or rate, of diflubenzuron in the diet did not affect the amount of diet consumed with any differences appearing associated with length of survival. Some larvae died after consuming very small amounts of diet while others, of the same size, consumed larger quantities suggesting that these may have ingested more diflubenzuron than necessary to kill them. It is probable that the amount consumed was related to the length of time before the next moult.

\section{Field}

Weather conditions in the areas of investigation, were dry in early spring but over the summer of 1999-2000 were generally cool and moist and favourable for porina survival. Flights of Wiseana moths began at all sites in October and continued into February (Fig. 1). A high proportion (approx. 40\% (Fig. 1)) of the flights at

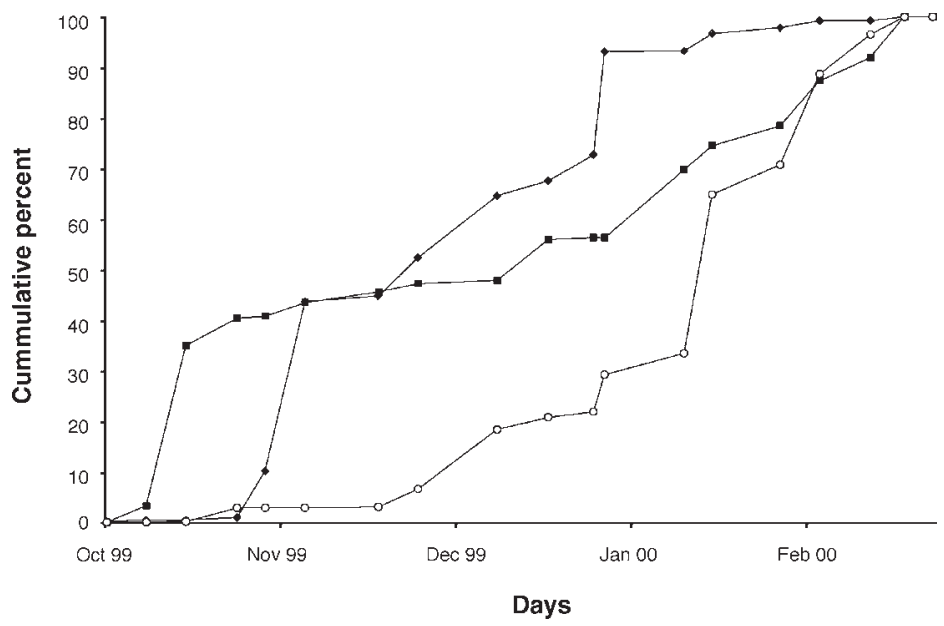

FIGURE 1: Wiseana spp. flights 1999-2000 at Mahinerangi ( $\diamond)$, Lumsden ( $\square$ ) and Owaka (O). 


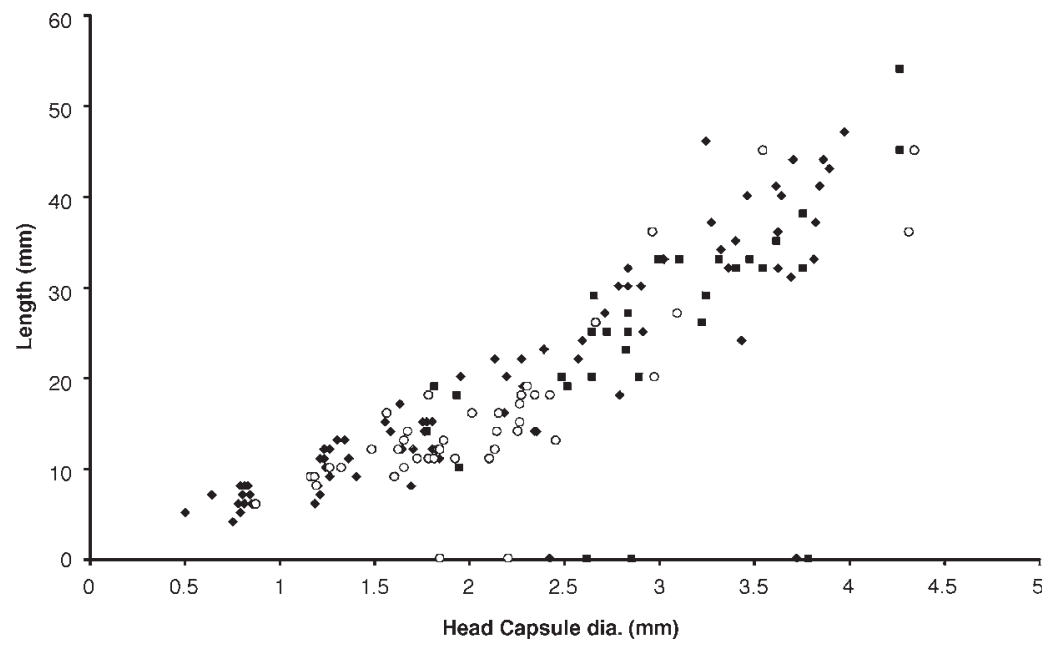

FIGURE 2: Size of Wiseana spp. larvae in pastures at Mahinerangi ( $\diamond)$, Lumsden (ם) and Owaka (O) in autumn 2000.

Mahinerangi and Lumsden occurred in spring when egg survival could be expected to be low but were subsequently reasonably evenly spread and resulted in evenly spread larval size ranges in autumn (Fig. 2). At Owaka most of the flights were in late summer (Fig. 1) and consequently there tended to be more small larvae present in autumn than large larvae (Fig. 2). Sampling of larvae in early autumn revealed a wide size range at all sites (Fig. 2) and covered the range of larval sizes used in the bioassays. The smallest larvae were unlikely to have contributed to pasture damage at this time. Conversely the largest larvae found were possibly close to maximum size and localised damage was apparent in the vicinity of their burrows

TABLE 1: Mean survival (\%) (SEM) of Wiseana spp. larvae after 14 and 28 days in bioassay 2 .

\begin{tabular}{lrrrrrr}
\hline & \multicolumn{6}{c}{ Diflubenzuron rate in diet } \\
Species & \multicolumn{2}{c}{ Untreated } & \multicolumn{2}{c}{ Low } & \multicolumn{2}{c}{ Field } \\
\hline W. copularis (late) & $96(4.2)$ & $60(12.6)$ & $12(6.8)$ & $0(0.3)$ & $5(3.4)$ & $0(0.1)$ \\
$W$. copularis (early) & $100(0.1)$ & $100(0.6)$ & $83(7.9)$ & $32(13.2)$ & $67(12.2)$ & $8(5.5)$ \\
$W$. cervinata (late) & $98(2.1)$ & $91(6.7)$ & $24(9.1)$ & $2(2.3)$ & $11(5.3)$ & $0(0.5)$ \\
$W$. cervinata (early) & $100(0.2)$ & $99(1.2)$ & $77(8.1)$ & $17(8.8)$ & $57(10.5)$ & $4(2.8)$ \\
$W$. jocosa & $100(0.2)$ & $97(2.8)$ & $80(7.6)$ & $8(5.9)$ & $61(10.0)$ & $1(1.4)$ \\
$W$. mimica & $100(0.1)$ & $100(0.2)$ & $85(6.5)$ & $51(11.7)$ & $69(10.0)$ & $16(7.8)$ \\
\hline
\end{tabular}

\section{DISCUSSION}

The bioassay results indicated that all species of Wiseana tested were killed by diflubenzuron. This is not unexpected given the range of insect taxa it is active against (Tomlin 1994). Smaller larvae, i.e. those in bioassay 1 , and $W$. copularis (late) and $W$. cervinata (late) in bioassay 2 , were killed more quickly than the larger larvae of all species in bioassay 2. This is consistent with the results of Wrenn et al. (1985) working with unidentified field collected porina larvae. This suggests that the varying levels of porina control effected by diflubenzuron in the southern South Island (Ferguson et al.1989; Ferguson et al.1996) is not associated directly with differential Wiseana 
species susceptibility to this material, but rather indirectly as a result of varying larval size distributions in pasture. Variation in effectiveness may also be due to diflubenzuron dilution or degradation within the environment. These factors were not included in the bioassay designs and it is probable that the larvae in these were exposed to greater concentrations than would occur in field situations.

In Otago and Southland, it is usually recommended that farmers apply diflubenzuron in late March and April. Ferguson et al. (1999) suggested that porina flight patterns may differ according to the proportion of the different species present. Flights dominated by $W$. cervinata peak in early summer while those dominated by $W$. copularis peak in late summer. Given conditions favourable for egg and early larval stage survival, the timing of the main flight period will determine the size of the majority of larvae present at the time of diflubenzuron application. Early summer flights result in large larvae in early autumn and correspondingly, late summer flights in smaller larvae. Autumn diflubenzuron application is likely to be more effective against larvae, arising from late flying moths, which are smaller and moulting more frequently than against larvae from earlier flying moths. From the flight data presented, a single diflubenzuron application in autumn could be expected to be more effective against populations such as those measured at Owaka where flights were predominantly late season, and larvae consequently small, rather than those at Mahinerangi and Lumsden. When adult flights are evenly spread and conditions favourable for larvae survival, two applications of diflubenzuron may be more effective in reducing porina larval numbers.

\section{CONCLUSION}

While there were some small differences in susceptibility to diflubenzuron between Wiseana species, its field effectiveness in areas where more than one species of Wiseana are present appears to be associated more with differences in the phenology of adult flights and subsequent larval development. Other environmental or climatic factors that favour the survival of one species over another may also be important. However, the timing of main flight periods and climatic conditions impacting on the survival of early larval stages are more important factors to consider than species composition when planning diflubenzuron application.

\section{ACKNOWLEDGEMENTS}

Thanks are due to the Nicolson, Copeland and Burgess families for their assistance with monitoring porina flights and allowing access to their properties; to Mr P.D. Johnstone for statistical analyses of the data; M. Slay for supplying moths from Makuri; R. Logan and A Goodman for technical assistance. This investigation was funded by the Foundation for Research, Science and Technology.

\section{REFERENCES}

Brown, B., Emberson, R.M. and Paterson, A.M., 1999. Mitochondrial COI and II provide useful markers for Wiseana (Lepidoptera: Hepialidae) species identification. Bull. Ent. Res. 89. 287-293.

Barratt, B.I.P, van Toor, R.F., Ferguson, C.M. and Stewart, K.M., 1990. Grassgrub and Porina in Otago and Southland. A Guide to Management and Control. 104pp.

Dodgshun, T.J., 1970. A semi-synthetic maintenance diet suitable for hepialid and melolonthid larvae. N.Z. Ent 4: 4. 78-79.

Dugdale, J.S., 1994. Fauna of New Zealand Number 30, Hepialidae (Insecta: Lepidoptera). Manaaki Whenua Press. 164pp.

Ferguson, C.M., Jones P.A. and Barratt B.I.P., 1989. Diflubenzuron for porina control in Otago. Proc. N.Z. Weed and Pest Control Conf. 42: 71-72.

Ferguson, C.M., Kearse, G.W. and Evans A.A., 1996. Evaluation of diflubenzuron for porina control in South Otago. Proc. N.Z. Plant Prot. Conf. 49: 249-252.

Ferguson, C.M., Logan, R.A.S. and Barratt, B.I.P., 1999.Wiseana flight patterns in Otago and Southland. Proc. N.Z. Plant Prot. Conf. 52: 275 
Herbert, J.M., 1994. Biochemical characterisation of Wiseana (Viette) moths and caterpillars (Lepidoptera: Hepialidae), and its implications for pest management. $\mathrm{PhD}$ Thesis, Victoria University, Wellington.

Stewart, K.M. and Ferguson, C.M., 1989. Chemical control of porina South Otago sheep pastures. N.Z. J. Ag. Res. 32: 395-400.

Stewart, K.M. and Ferguson, C.M., 1992. Control of Wiseana spp (Lepidoptera: Hepialidae) by sheep grazing in South Otago. N.Z. J. Ag. Res. 35: 429-433.

Tomlin, C. (Ed), 1994. The Pesticide Manual, incorporating The Agrochemicals Handbook, 10th edition. Crop Protection Publications. British Crop Protection Council, United Kingdom. 1341pp.

Wrenn, N.R., McGhie, R.A. and Pottinger, R.P., 1985. Bioassay and field experiments for evaluation of difluron for porina caterpillar control in pasture. Proc. $4^{\text {th }}$ Australasian. Conf. On Grassland Invert. Ecol.: 286-292. 